\title{
CERVICAL AND OCULAR VESTIBULAR EVOKED MYOGENIC POTENTIALS IN INDIVIDUALS WITH SEVERE TO PROFOUND HEARING LOSS
}

\author{
Shalini Bansal, Shruti Sahni, Sujeet Kumar Sinha \\ Department of Audiology, All India Institute of Speech and Hearing, Manasagangothri, Karanataka, India \\ Corresponding author: Sujeet Kumar Sinha, Department of Audiology, All India Institute of Speech and \\ Hearing, Manasagangothri, Mysore-570006, Karanataka, India, e-mail: sujitks5@gmail.com
}

\begin{abstract}
Background: Vestibular evoked myogenic potential (VEMP) is a test to assess the functioning of otolith organs of the inner ear. Cervical VEMPs (cVEMPs) assess the saccule and the inferior vestibular nerve, whereas ocular VEMPs (oVEMPs) assess the utricle and superior vestibular nerve. In individuals with sensorineural hearing loss, disturbances of cochlear function could accompany vestibular impairment since both these parts of the inner ear are anatomically related. The aim of the present study was to find out the prevalence of cVEMPs and oVEMPs in individuals with congenital severe to profound sensorineural hearing loss.
\end{abstract}

Material and methods: There were 46 participants in the present study: 23 with normal hearing and 23 with bilateral severe to profound hearing loss, and cVEMPs and oVEMPs were recorded from all of them.

Results: cVEMPs were present in $100 \%$ of subjects, both in the control and experimental groups; oVEMPs were present in $100 \%$ of the control and $66 \%$ of the experimental group. In hearing impaired individuals no correlation was found between cVEMPs and oVEMPs, although a Mann-Whitney test revealed that the amplitude of cVEMPs and oVEMPs were significantly smaller in the hearing impaired group compared to normals.

Conclusions: The results indicate impairment of both utricular and saccular function in individuals with severe to profound hearing loss. Also oVEMPs were absent in more individuals compared to cVEMPs, which suggests that utricular function is more linked with the cochlea compared to that of the saccule.

Keywords: cVEMPs • oVEMPs • severe to profound hearing loss $\bullet$ saccule $\bullet$ utricle

\section{POTENCIALES VESTIBULARES MIOGÉNICOS EVOCADOS (PVME) CERVICALES Y OCULARES EN PERSONAS CON LA PÉRDIDA AUDITIVA DE SIGNIFICATIVA A PROFUNDA}

\section{Resumen}

Introducción: El estudio de los potenciales vestibulares miogénicos evocados (PVME) sirve para evaluar el funcionamiento de los órganos otolíticos del oído interno. Los PVME cervicales (cPVME) sirven para evaluar el utrículo y la parte superior del nervio vestibular. En personas con la pérdida de audición neurosensorial, la disfunción coclear puede ser acomañada de trastornos vestibulares, dado que estas partes del oído interno están anátomicamente asociadas. El objetivo del presente estudio ha sido evaluar la presencia de cPVME o de oPVME en personas con la pérdida de audición neurosensorial congénita, al menos significativa.

Material y método: En la prueba han participado 46 personas: 23 con audición normal y 23 con pérdida auditiva bilateral del grado de significativo a profundo; en ambos grupos se ha realizado el registro de los cPVME y de oPVME.

Resultados: Los CPVME han sido presentes en el 100\% de participantes de la prueba, tanto en el grupo de control, como y en el grupo de estudio. Los oPVME han sido presentes en el 100\% de personas del grupo de control y en el $66 \%$ del grupo de estudio. En personas con la pérdida auditiva no se ha constatado la corrrelación entre los CPVME y los oPVME, aunque la prueba de Mann-Whitney ha demostrado que las amplitudes de los cPVME y de oPVME han sido considerablemente inferiores en personas con la pérdida auditiva en comparación con las de la audición normal. 
Conclusiones: Los resultados demuestran que las personas con la pérdida auditiva de significativa a profunda tienen la disfunción tanto de la función del utrículo, como y del sáculo. Además, los oPVME han sido ausentes en mayor número de personas que los cPVME, lo que sugiere que la función del ultrículo está más relacionada con el caracol que la función del sáculo.

Palabras clave: $\mathrm{CPVME} \bullet \mathrm{oPVME} \bullet$ pérdida auditiva de significativa a profunda • sáculo • ultrículo

\section{ШЕЙНЫЕ И ЗРИТЕЛЬНЫЕ ВЫЗВАННЫЕ ВЕСТИБУЛЯРНЫЕ МИОГЕННЫЕ ПОТЕНЦИАЛЫ У ЛЮДЕЙ С ТУГОУХОСТЬЮ - ОТ ЗНАЧИТЕЛЬНОЙ ДО ГЛУБОКОЙ}

\section{Изложение}

Введение: Исследование вызванных вестибулярных миогенных потенциалов (VEMP) служит для оценки функционирования отолитового аппарата внутреннего уха. Шейные VEMP (cVEMPs) служат для оценки мешочка и нижней части вестибулярного нерва, тогда как зрительные VEMP (oVEMPs) служат для оценки маточки и верхней части вестибулярного нерва. У людей с перцептивной тугоухостью нарушения функции улитки могут сопутствовать вестибулярные нарушения, потому что эти две части внутреннего уха анатомитески связанные. Цель настоящего исследования - оценка наличия cVEMPs и oVEMPs у людей с врожденной, по крайней мере значительной перцептивной тугоухостью.

Материал и метод: В исследовании участвовало 46 человек: 23 с нормальным слухом, и 23 с двусторонней тугоухостью - от значительной до глубокой. У всех были сделаны записи cVEMPs и oVEMPs.

Результаты: cVEMPs были наличны у 100\% исследованных людей в контрольной и в исследуемой группе. oVEMPs были наличны у $100 \%$ людей из контрольной группы и 66\% из иследуемой группы. У людей с тугоухостью не была обнаружена корреляция между cVEMPs и oVEMPs, хотя тест Манна-Уитни показал, что амплитуды cVEMPs и oVEMPs были значительно меньше у тугоухих людей в сравнении с нормально слышащими людьми.

Итоги: Итоги показывают, что у людей с тугоухостью - от значительной до глубокой, имеется нарушение функции маточки и мешочка. Кроме того, oVEMPs отсутствовали у большего числа людей, чем cVEMPs. Это показывает более сильную связь с улиткой функции маточки, чем функции мешочка.

Ключевые слова: cVEMPs • oVEMPs • тугоухость - от значительной до глубокой • мешочек • маточка

\section{SZYJNE I WZROKOWE MIOGENNE PRZEDSIONKOWE POTENCJAŁY WYWOŁANE U OSÓB Z NIEDOSŁUCHEM ZNACZNYM DO GŁĘBOKIEGO}

\section{Streszczenie}

Wprowadzenie: Badanie miogennych przedsionkowych potencjałów wywołanych (VEMP) służy do oceny funkcjonowania narządów otolitowych ucha wewnętrznego. Szyjne VEMP (cVEMPs) służą do oceny woreczka i dolnej części nerwu przedsionkowego, podczas gdy wzrokowe VEMP (oVEMPs) służą do oceny łagiewki i górnej części nerwu przedsionkowego. U osób z niedosłuchem odbiorczym zaburzenia funkcji ślimaka mogą towarzyszyć zaburzeniom przedsionkowym, gdyż obie te części ucha wewnętrznego są powiązane anatomicznie. Celem obecnego badania była ocena występowania cVEMPs i oVEMPs u osób z wrodzonym, co najmniej znacznym niedosłuchem odbiorczym.

Materiał i metoda: W badaniu wzięło udział 46 osób: 23 ze słuchem prawidłowym i 23 z obustronnym niedosłuchem stopnia od znacznego do głębokiego, u wszystkich dokonano zapisu cVEMPs i oVEMPs.

Wyniki: cVEMPs były obecne u 100\% badanych osób, zarówno w grupie kontrolnej jak i badanej. oVEMPs było obecne u 100\% osób z grupy kontrolnej i 66\% z grupy badanej. U osób z niedosłuchem nie stwierdzono korelacji między cVEMPs i oVEMPs, chociaż test Manna-Whitneya wykazał, że amplitudy cVEMPs i oVEMPs były istotnie mniejsze u osób niedosłyszących w porównaniu do normalnie słyszących.

Wnioski: Wyniki wskazują, że u osób z niedosłuchem znacznym do głębokiego występuje upośledzenie zarówno funkcji łagiewki, jak i woreczka. Ponadto oVEMPs były nieobecne u większej liczby osób niż cVEMPs, co sugeruje silniejszy związek ze ślimakiem funkcji łagiewki niż funkcji woreczka.

Słowa kluczowe: cVEMPs • oVEMPs • niedosłuch znaczny do głębokiego • woreczek • łagiewka 


\section{Background}

In humans, postural stability is maintained by the visual, proprioceptive, and vestibular systems. In the vestibular system, the semicircular canals and the otolith organs (saccule and utricle) are responsible for maintaining postural stability. The semicircular canals help in balancing during angular acceleration and the otolith organs help in balancing during linear acceleration. As the vestibular system consists of multiple structures, a particular test cannot assess the functioning of all the structures. Until the vestibular evoked myogenic potential (VEMP) came into the picture, it was not possible to assess the otolith organs.

VEMP is a non-invasive test to assess the functioning of the otolith organs of the inner ear. It is a short latency muscle potential which is elicited by the presentation of a loud sound. One variant of VEMP is cervical VEMP (cVEMPs) which has been found to originate from the saccule $[1,2]$. When a loud sound stimulus is given it stimulates the saccule which activates the inferior vestibular nerve and reaches the vestibular nucleus in the brainstem $[3,4]$. Impulses from the vestibular nucleus are sent to the sternocleidomastoid muscle (mostly ipsilaterally) through the medial vestibulospinal tract (MVST) [4]. cVEMPs consist of a biphasic peak with positive peak at approximately $13 \mathrm{~ms}$ and a negative peak at approximately $23 \mathrm{~ms}$, and can be traced to a saccular response to an air conduction stimulus.

Another variant of VEMP is the ocular VEMP (oVEMPs), which has been introduced recently and is thought to be utricular in origin [5-8]. It is mediated through the vestibulo-ocular reflex pathway. The acoustic stimulus activates the utricle and travels via the superior vestibular nerve to reach the medial longitudinal fasciculus, where it decussates and ends at the oculo-motor nuclei and ocular nerve, which generate triphasic myogenic potentials with a negative peak, N10, a positive peak, P14, and another negative peak at approximately $23 \mathrm{~ms} .[6,9,10]$.

cVEMPs and oVEMPs have been found to be useful in diagnosis of the saculocollic and utriculo-ocular pathways, respectively, in Meniere's disease [11], vestibular neuritis [12], superior canal dehiscence syndrome [13], auditory neuropathy [14], and labrynthitis [15]. Studies have also revealed a saccular dysfunction in hearing impaired individuals based on cVEMPs results [16-19]. However, there is dearth of information on utricular involvement in individuals with severe to profound hearing loss. It is highly possible that, along with saccular dysfunction, utricular dysfunction may also be involved. To the best of our knowledge, this is the first study which has evaluated utricular dysfunction utilising oVEMPs in sensorineural hearing loss.

The aim of the present study was to find out the prevalence of cVEMPs and oVEMPs and to find a correlation between cVEMPs and oVEMPs in individuals with severe to profound hearing loss.

\section{Material and Method}

\section{Participants}

\section{Experimental group}

A total of 45 ears from 23 participants of age 15-30 years were included in the study, all being diagnosed with bilateral severe to profound sensorineural hearing loss as evidenced by pure tone hearing thresholds for octave frequencies between $250 \mathrm{~Hz}$ to $8000 \mathrm{~Hz}$ for air conduction and $250 \mathrm{~Hz}$ to $4000 \mathrm{~Hz}$ for bone conduction, respectively, and normal middle ear function as revealed by immittance evaluation. UCL for speech was found to be greater than $100 \mathrm{~dB}$ HL in both ears. It was ensured that none of the participants had a history or presence of any other otological problems (like ear discharge, ear pain, or itching), or neurological or neuromuscular problems. None of the individuals had any syndromic hearing loss.

\section{Control group}

A total of 23 participants (45 ears) in the age-range 15-30 years were considered for the study. All participants were diagnosed to have normal hearing sensitivity as evidenced by pure tone audiometry and did not have the presence or history of any external or middle ear related problems. The participants did not report a history or presence of vestibular symptoms.

\section{Instrumentation}

A calibrated two-channel clinical audiometer (Orbitor-922 V-2x G N Otometrics, Taastrum, Denmark) with TDH 39 headphones (Telephonics, Farmingdale, NY) was utilised for estimation of air conduction pure tone thresholds. Bone conduction threshold was estimated using a B-71 bone vibrator (Radioear, Kimmetrics, Smithsburg, MD). Middle ear status was evaluated by using a calibrated GrasonStadler Tympstar System (GSI Viasys Healthcare, WI). A Bio-Logic Navigator Pro System (Natus Medical Incorporated, San Carlos, CA) was used to record VEMPs with an insert ER-3A earphone (Etymotic Research, Elk Grove Village, IL). All measurements were carried out in an acoustically treated double room and noise levels were maintained within permissible limits as given by ANSI S-3 [20].

\section{Procedure}

Pure-tone thresholds were obtained for all participants using a modified version of the Hughson and Westlake procedure [21] at octave frequencies between $250 \mathrm{~Hz}$ to 8000 $\mathrm{Hz}$ for air conduction and between $250 \mathrm{~Hz}$ to $4000 \mathrm{~Hz}$ for bone conduction. UCL was determined in both ears for air conducted speech stimuli using the ascending method. Immittance audiometry was carried out in both ears using a probe tone of $226 \mathrm{~Hz}$. Tympanometry was done initially, followed by ipsilateral and contralateral acoustic reflex threshold measurement for stimuli of 500, 1000, 2000, and $4000 \mathrm{~Hz}$.

This was followed by recording of cVEMPs and oVEMPs from all participants. Electrode sites were cleaned with abrasive gel (Nuprep), silver chloride disc electrodes were 
Bansal et al. - Cervical and Ocular Vestibular Evoked Myogenic Potentials in Individuals with Severe...

Table 1. Mean and standard deviation(SD) for CVEMPs and oVEMPs potentials parameters in control group

\begin{tabular}{ccccccc}
\hline & \multicolumn{1}{c}{ cVEMPs } & & oVEMPs \\
\cline { 2 - 6 } & $\begin{array}{c}\text { P1 Latency } \\
(\mathbf{m s e c})\end{array}$ & $\begin{array}{c}\text { N1 Latency } \\
(\mathbf{m s e c})\end{array}$ & $\begin{array}{c}\text { P1-N1 amplitude } \\
(\boldsymbol{\mu} \mathbf{v})\end{array}$ & $\begin{array}{c}\text { N1 Latency } \\
(\mathbf{m s e c})\end{array}$ & $\begin{array}{c}\text { P1 Latency } \\
(\mathbf{m s e c})\end{array}$ & $\begin{array}{c}\text { N1-P1 amplitude } \\
(\boldsymbol{\mu} \mathbf{v})\end{array}$ \\
\hline Mean & 14.27 & 20.18 & 55.98 & 9.85 & 14.45 \\
\hline SD & 1.58 & 4.14 & 36.34 & 0.81 & 1.24 \\
\hline
\end{tabular}

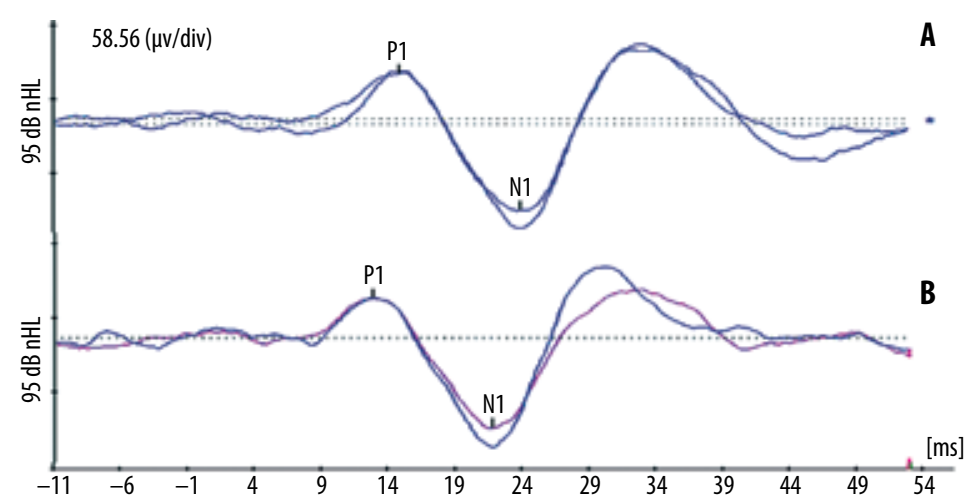

Figure 1. (A) Representative cVEMPs in a participant from control group. (B) CVEMPs in a participant from experimental group

placed on the sites with conduction paste, and surgical tape was used to hold them in place. For cVEMPs recording, the non-inverting electrode $(+)$ was placed at the midpoint of the sternocleidomastoid muscle of the side being stimulated, while the inverting electrode $(-)$ was placed at the sternoclavicular junction and the ground electrode was placed on the lower forehead. Absolute electrode impedance and inter-electrode impedance was maintained below $5000 \mathrm{ohms}$ and $2000 \mathrm{ohms}$ respectively.

While recording cVEMPs, participants were instructed to sit straight and turn their head to the opposite side of the ear to which the stimulus was presented, so as to activate the ipsilateral sternocleidomastoid (SCM) muscle, as it gives more reliable and greater amplitude. The participants were asked to maintain the same posture throughout the test run. cVEMPs were determined using a $500 \mathrm{~Hz}$ toneburst ( 2 cycles rise, 0 cycles plateau, and 2 cycles fall, Blackman weighting function) presented at a rate of $5.1 / \mathrm{sec}$ using rarefaction polarity. A $500 \mathrm{~Hz}$ tone-burst stimulus was used as this gives a larger amplitude cVEMPs [22]. Stimuli was presented to the test ear at an intensity of $95 \mathrm{~dB}$ $\mathrm{nHL}$ using ER-3A insert ear phones. The responses were recorded for a post-stimulus period of $64 \mathrm{~ms}$ and were then amplified $(\times 5000)$ and band pass filtered $30-1500 \mathrm{~Hz}$. Averaging was done for a total of 200 stimuli. Recording was done twice to ensure reproducibility of the responses.

For recording oVEMPs, the inverting electrode (-) was placed inferior to the lower eyelid of the eye contralateral to the side being stimulated, the non-inverting electrode (+) was placed immediately inferior to the inverting electrode, and the ground electrode was placed on the lower forehead. Absolute electrode impedances and inter-electrode impedances were maintained below $5000 \mathrm{ohms}$ and 2000 ohms respectively. Participants were instructed to maintain an upper gaze throughout the test run.
Stimuli used to record oVEMPs were identical to stimuli used to record cVEMPs (a $500 \mathrm{~Hz}$ tone burst presented at $5.1 / \mathrm{sec}$ using rarefaction polarity). The stimuli were presented monaurally at a single intensity of $95 \mathrm{~dB}$ nHL using ER-3A insert ear phones. Responses were recorded for a post-stimulus period of $64 \mathrm{~ms}$ and averaging was done for 100 stimuli. Electrical responses were amplified $(\times 5000)$ and bandpass filtered $10-1000 \mathrm{~Hz}$. oVEMPs responses were recorded twice in each ear to ensure reproducibility.

Analysis of cVEMPs focused on latency of the P1 and N1 peaks and P1-N1 amplitude, while for oVEMPs the parameters of interest were the latency of the $\mathrm{N} 1$, and $\mathrm{P} 1$ peaks, and the amplitude of N1-P1 complex.

\section{Results}

\section{Control group}

Both cVEMPs and oVEMPs were found to be present in 100\% of participants $(n=45)$. P1 latency, N1 latency, and P1-N1 amplitude complex were calculated for cVEMPs, while N1 latency, P1 latency, and N1-P1 amplitude were calculated for oVEMPs. Descriptive statistics involved the mean and standard deviation of the latency and amplitude of cVEMPs and oVEMPs parameters, and the values are shown in Table 1.

\section{Experimental group}

cVEMPs were present in 45 out of 45 (100\%) of the ears studied. Figure 1 shows cVEMPs recordings from the control and experimental groups.

Descriptive statistics involved the mean and standard deviation of the latency and amplitude of cVEMPs parameters. The values of mean and standard deviation for N1 latency, P1 latency, and P1-N1 amplitude are shown in Table 2. 
Table 2. Mean and standard deviation (SD) for cVEMPs parameters in experimental group

\begin{tabular}{cccc}
\hline cVEMPs & N & Mean & SD \\
\hline N1 Latency (msec) & 45 & 20.58 & 1.53 \\
\hline P1 Latency (msec) & 45 & 13.90 & 1.19 \\
\hline P1-N1 Complex amplitude $(\mu \mathrm{V})$ & 45 & 41.57 & 37.72 \\
\hline
\end{tabular}

${ }^{*} \mathrm{~N}$ - number of ears responses present.

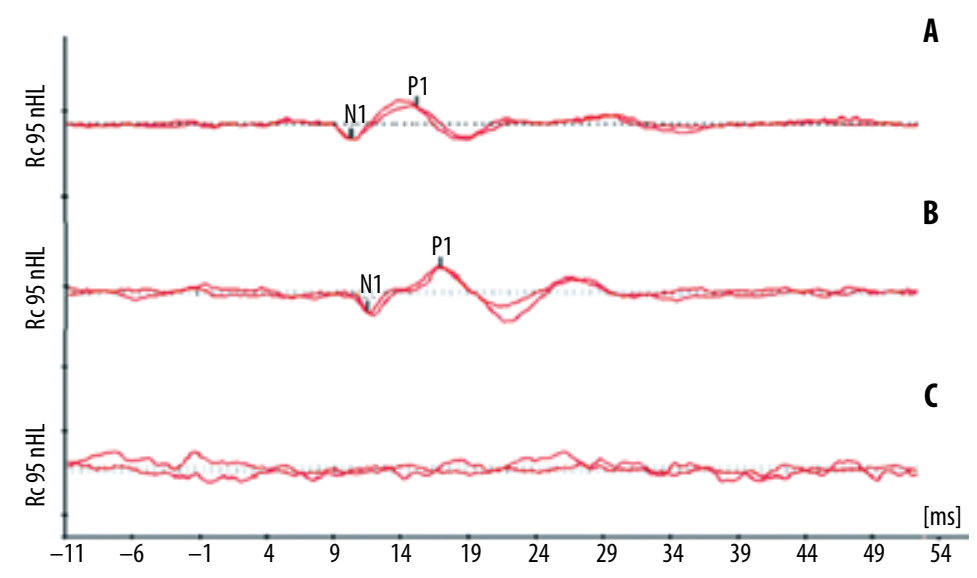

Figure 2. (A) oVEMPs in a participant from control group. (B) oVEMPs in a participant from experimental group. (C) Absence of oVEMPs in another participant from experimental group

Table 3. Mean and standard deviation (SD) for oVEMPs parameters in experimental group

\begin{tabular}{cccc}
\hline oVEMPs & N & Mean & SD \\
\hline N1 Latency $(\mathrm{msec})$ & 30 & 9.89 & 0.51 \\
\hline P1 Latency $(\mathrm{msec})$ & 30 & 14.52 & 1.09 \\
\hline P1-N1 Complex amplitude $(\mu \mathrm{V})$ & 30 & 2.84 & 2.49 \\
\hline
\end{tabular}

${ }^{*} \mathrm{~N}$ - number of ears responses present.

oVEMPs were present in 30 out of a total of 45 ears (67\%). Figure 2 shows oVEMPs recordings from the control and experimental groups.

Descriptive statistics involved the mean and standard deviation of the latency and amplitude of oVEMPs parameters, and the values of mean and standard deviation for $\mathrm{N} 1$ latency, P1 latency and N1-P1 amplitude complex are shown in Table 3.

Correlation between cVEMPs and oVEMPs in the experimental group

Spearman's correlation analysis was done to find the correlation between cVEMPs and oVEMPs in individuals with severe to profound hearing loss. A significant correlation was found between P1 latency of oVEMPs and N1 latency of cVEMPs $\left(r_{s}=0.62, p<0.01\right)$. No significant correlation was found between N1 latency of cVEMPs and N1 latency of oVEMPs $(r=0.14, p=0.47)$; P1 latency of cVEMPs and P1 latency of oVEMPs $\left(r_{s}=0.26, p=0.17\right) ; \mathrm{P} 1$ latency of cVEMPs and N1 latency of oVEMPs $\left(r_{s}=0.20, p=0.30\right)$; or P1-N1 amplitude complex of cVEMPs and N1-P1 amplitude complex of oVEMPs $\left(r_{s}=0.22, p=0.15\right)$.
Comparison of cVEMPs and oVEMPs in the control and experimental groups

A non-parametric Mann-Whitney U-test was done to find out if there was a significant difference in latency and amplitude between the normal and hearing impaired groups. Figure $3 \mathrm{~A}, 3 \mathrm{~B}$ show the mean and standard deviation for latency and amplitude of cVEMPs for both the normal and hearing impaired.

The non-parametric Mann-Whitney U-test did not show a significant difference in cVEMPs P1 latency $(Z=1.18$, $p>0.05)$ or cVEMPs N1 latency $(Z=0.16, p>0.05)$ between the normal and hearing impaired groups. However, a significant difference was seen in the P1-N1 amplitude complex of cVEMPs $(Z=2.23, p<0.05)$ between the normal and hearing impaired groups.

Figure 4A, 4B show the mean and standard deviation for latency and amplitude of oVEMPs for the normal and hearing impaired groups.

A non-parametric Mann-Whitney U-test did not show a significant difference in N1 latency of oVEMPs $(Z=3.52$, 
A
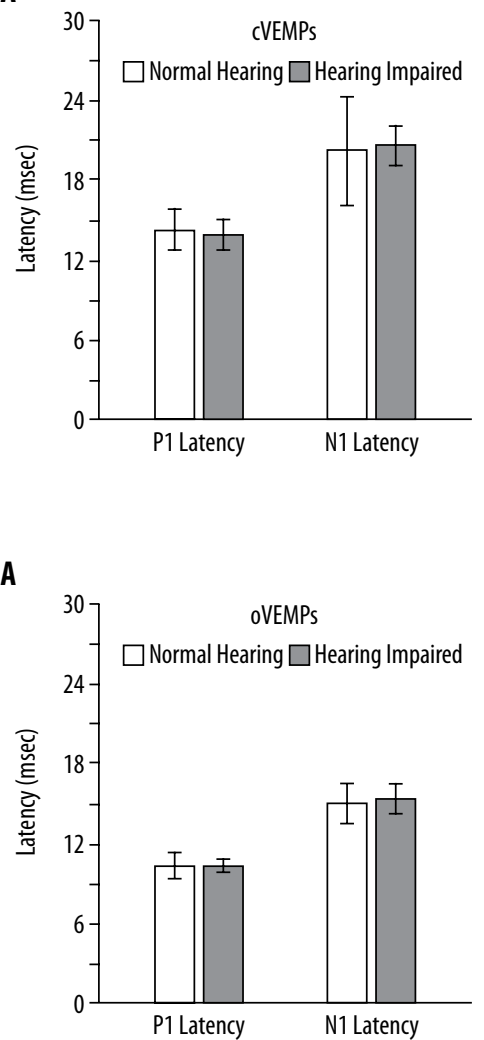

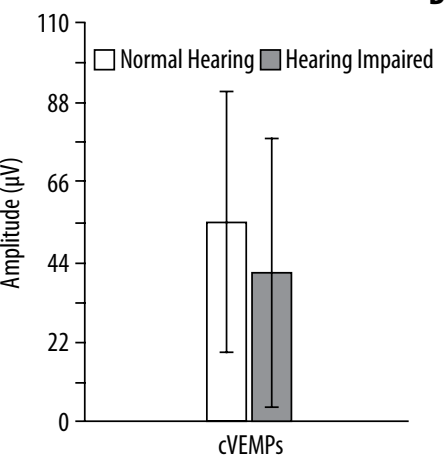

B

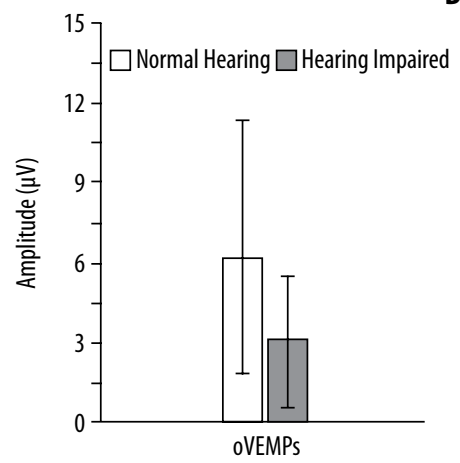

Figure 3. (A) Mean and SD of latency of CVEMPs in control and experimental groups. (B) Mean and SD of amplitude of cVEMPs in control and experimental groups $p>0.05)$, P1 latency of oVEMPs $(Z=0.265, p>0.05)$ between control and experimental groups. However, a significant difference was seen in N1-P1 amplitude complex of oVEMPs $(Z=3.59, p<0.05)$ between the control and experimental groups.

To summarise, cVEMPs were present, whereas oVEMPs were absent in 15 out of 45 ears in individuals with severe to profound hearing loss. cVEMPs and oVEMPs were present in all control group subjects. Further, there was no significant difference in latency of cVEMPs and oVEMPs between control and experimental groups, whereas the amplitude of cVEMPs as well as oVEMPs were reduced in the hearing loss population compared to normal hearing individuals. Also, there was no significant correlation between cVEMPs and oVEMPs parameters in hearing impaired individuals.

\section{Discussion}

Since there were only two groups in the present study, a $t$-test was preferred to ANOVA. Further a parametric $t$ test was not administered because of the unequal sample sizes in the two groups of data. The results of this study revealed that individuals with severe to profound SNHL have a prevalence of cVEMPs of $100 \%$. Compared to the earlier studies, the prevalence of cVEMPs in the present study is higher. Singh et al. [16] reported a prevalence of cVEMPs in $87 \%$ children of age $4-12$ years who had severe to profound hearing loss; on the other hand, a study by Shinjo et al. [17] revealed cVEMPs in $75 \%$ of the subjects with severe to profound hearing loss. Also, Ochi \&
Ohashi [18] showed the prevalence of cVEMPs in $66.7 \%$ of ears. A prevalence of cVEMPs in 53\% of ears in 33 children with a mean age of 6.9 years was reported by Jafari \& Malayeri [23]. Rosengren \& Colebatch [24] reported the presence of cVEMPs in 7 out of 14 subjects (50\%) with severe to profound hearing loss when stimulated via bone conduction. Tribukait et al. [25] found an absence of cVEMPs in $22 \%$ of participants, an asymmetric VEMP in $19 \%$, and normal VEMP in $58 \%$ of participants out of 36 children with profound deafness when $0.1 \mathrm{~ms}$ rarefaction clicks were used as stimulus. Also, Zhou et al. [19] reported the presence of abnormal VEMPs with reduced amplitude and higher thresholds in 21 out of 23 participants $(91 \%)$ in the age range of 2 to 16 years. The differences in prevalence rates across studies could be due to different methodologies or perhaps to the different ages of participants.

In the present study, oVEMPs responses were absent in $33 \%$ of individuals with hearing loss. Here, the present data showed that ocular VEMPs were more frequently absent than cervical cVEMPs, suggesting that utricular function could be more closely linked to the cochlea than saccular function in individuals with severe to profound hearing loss. In an earlier study, Tribukait et al. [25] reported, based on the subjective visual horizontal test, that hearing levels were more correlated with utricular function than saccular function in individuals with severe to profound sensorineural hearing loss. Tribukait et al. [25] reported that the cochlea is more closely related to the utricle than to any other sensory receptors of the inner ear. Thus, the present study supports the findings by Tribukait et al. [25] 
and, based on the results, it is suggested that vestibular function should be checked in these individuals.

In the present study we also found that the amplitude of the P1-N1 of cVEMPs, and N1-P1 peak of oVEMPs, were smaller for the hearing impaired group compared to the normal hearing group. This suggests that there could be an abnormality of both the saccule as well as the utricule in individuals with severe to profound sensorineural hearing loss. In individuals with hearing impairment, the abnormality in vestibular function could be due to a similarity between the cochlear and vestibular structures $[16,19,24-26]$.

Also, there was no correlation between the cVEMPs and oVEMPs tests in these individuals, except for P1 latency of oVEMPs and N1 latency of cVEMPs. Lack of association between cVEMPs and oVEMPs could be due to the fact that oVEMPs reflect different functions from cVEMPs, as indicated in previous reports $[27,28]$. The oVEMPs assess the utricule whereas the cVEMPs assess the saccule, and also the cVEMPs pathways are longer compared to oVEMPs pathways $[27,28]$. cVEMPs are recorded from the sternocleidomastoid muscle, whereas oVEMPs are recorded from the inferior oblique muscle, and the former is thicker than the latter $[27,28]$. All these variations could have resulted in lack of correlation between cVEMPs and oVEMPs in the present study. The correlation of the latency of one cVEMPs peak and one oVEMPs peak could have been due to chance.

None of the participants reported any vestibular signs and symptoms. Absence of vestibular symptoms in individuals

\section{References:}

with severe to profound hearing loss could be due to a bilateral distribution of the disorder. Also, it is possible that a long-term central vestibular compensation (which occurs via the proprioceptive and visual systems) could have occurred in these individuals, meaning that there were no vestibular signs or symptoms.

\section{Summary and Conclusions}

The present study revealed the presence of both cVEMPs and oVEMPs in both the control and experimental groups. However, a lower prevalence rate of oVEMPs $(66 \%)$ is suggestive of utricular function being more linked to the cochlea than saccular function in individuals with severe to profound hearing loss. Also no correlation was found between cVEMPs and oVEMPs. The results of the present study also revealed a significant difference between cVEMPs and oVEMPs amplitudes between control and experimental groups. To conclude, both the utricle and saccule is impaired in individuals with severe to profound hearing loss, and thus, along with other audiological testing, vestibular testing should also be carried out for this group of individuals.

\section{Acknowledgement}

The authors are thankful to the HOD Audiology for permitting us to use instruments in the Audiology department. The authors are thankful to all the participants.

\section{Conflict of interest}

The authors do not have any conflict of interests.
1. Colebatch J, Halmagyi G, Skuse N. Myogenic potentials generated by a click evoked vestibulocollic reflex. J Neurol Neurosurg Psychiatry, 1994; 57(2): 190-97.

2. Todd N, Cody F, Banks JA. Saccular origin of frequency tuning in myogenic vestibular evoked potentials? Implications for human responses to loud sounds. Hear Res, 2000; 141(1-2): $180-88$.

3. Hall J. New handbook of auditory evoked responses. 2007; Boston, MA: Pearson Education, Inc.

4. Haque A, Dickman J. Vestibular system function: from physiology to pathology. In: Clark W and Ohlemiller K (eds.), Anatomy and physiology of hearing for audiologists 2008; (pp. 284308). Clifton Park, NY: Thomson Delmar Learning.

5. Halmagyi GM, Curthoys IS, Colebatch JG, Aw ST. Vestibular responses to sound. Ann NY Acad Sci, 2005; 1039: 54-67.

6. Curthoys IS. A balanced view of the evidence leads to sound conclusions. Clin Neurophysiol, 2010; 121(6): 977-78.

7. Welgampola M, Carey J. Waiting for the evidence: VEMP testing and the ability to differentiate utricular versus saccular function. J Otolaryngol Head Neck Surg, 2010; 143(2): 281-83.

8. Brandt T, Strupp M. Clicking the eye muscles? The diagnostic value of sound-evoked vestibular reflexes. Neurology, 2010; 75: 848-49.

9. Welgampola $\mathrm{M}$. The human sound-evoked vestibulo-ocular reflex and its electromyographic correlate. Clin Neurophysiol, 2009; 120(1): 158-66.
10. Manzari L, Burgess AM, Curthoys IS. Dissociation between cVEMPs and oVEMPs responses: different vestibular origins of each VEMP? Eur Arch Otorhinolaryngol, 2010; 267(9): 1487-89.

11. Kim MB, Choi J, Park GY, Cho YS, Hong SH, Chung WH. Clinical value of vestibular evoked myogenic potential in assessing the stage and predicting the hearing results in Ménière's disease. Clin Exp Otorhinolaryngol, 2013; 6(2): 57-62.

12. Shin B-S, Oh S-Y, Kim JS, Kim T-W, Seo M-W, Lee H, Park Y-A. Cervical and ocular vestibular-evoked myogenic potentials in acute vestibular neuritis. Clin Neurophysiol, 2012; 123(2): 369-75.

13. Zuniga MG, Janky KL, Nguyen KD, Welgampola MS, Carey JP. Ocular versus cervical VEMPs in the diagnosis of superior semicircular canal dehiscence syndrome. Otol Neurotol, 2013; 34(1): 121-26.

14. Sinha SK, Kruthika S, Sharanya R. Cervical and ocular vestibular evoked myogennic potentials test results in individuals with auditory neuropathy spectrum disorders. Audiology Research, 2013; 3: e4: 26-30.

15. Moon IH, Lee CG, Park MK, Lee JD. Cervical vestibular evoked myogenic potential and ocular vestibular evoked myogenic potential in patients with vestibular neuritis and acute viral labyrinthitis. Res Vestib Sci, 2012; 11(3): 92-96.

16. Singh S, Gupta RK, Kumar P. Vestibular evoked myogenic potentials in children with sensorineural hearing loss. Int J Pediatr Otorhinolaryngol, 2012; 76: 1308-11. 
17. Shinjo Y, Jin Y, Kaga K. Assessment of vestibular function of infants and children with congenital and acquired deafness using the ice water caloric test, rotational chair test and a vestibular evoked myogenic potential recording. Acta Otolaryngol, 2007; 127: 736-47.

18. Ochi K, Ohashi T. Sound-evoked myogenic potentials and responses with 3-ms latency in auditory brainstem response. Laryngoscope, 2001; 111: 1818-21.

19. Zhou G, Keena MA, Stevens K, Licaameli G. Assessment of saccular function in children with sensorineural hearing loss. Arch Otolaryngol Head Neck Surg, 2009; 35: 40-44.

20. American Standards Institute. American National Standards maximum permissible ambient noise levels for audiometric test rooms. ANSI S3.1. New York: American National Standards Institute; 1991.

21. Carhart R, Jerger JF. Preferred method for clinical determination of pure-tone thresholds. J Speech Hear Disord, 1959; 24: 330-45.

22. Kumar K, Sinha SK, Bharti AK, Barman A. Comparison of vestibular evoked myogenic potentials elicited by click and short duration tone burst stimuli. J Laryngol Otol, 2011; 125: 343-47.
23. Jafari $Z$, Malayeri S. The effect of saccular function static balance ability of profound hearing impaired children. Int J Pediatr Otorhinolaryngol, 2011; 75(7): 919-24.

24. Rosengren SM, Colebatch JG. Vestibular evoked potentials (VsEPs) in patients with severe to profound bilateral hearing loss. Clin Neurophysiol, 2006; 117: 1145-53.

25. Tribukait A, Brantberg K, Bergenius J. Function of semicircular canals, utricles and saccules in deaf children. Acta Otolaryngol, 2004; 124: 41-48.

26. Cushing SL, Papsin BC, Rutka JA, James AL, Gordon KA. Evidence of vestibular and balance dysfunction in children with profound sensorineural hearing loss using cochlear implants. Laryngoscope, 2008; 118: 1814-23.

27. Murofushi T, Nakahara H, Yoshimura E, Tsuda Y. Association of air-conducted sound oVEMPs findings with cVEMPs and caloric test findings in patients with unilateral peripheral vestibular disorders. Acta Otolaryngol, 2011; 131(9): 945-50.

28. Chiarovano E, Zamith F, Vidal P, Waele C. Ocular and cervical VEMPs: a study of 74 patients suffering from peripheral vestibular disorders. Clin Neurophysiol, 2011; 122: 1650-59. 